\section{Analysis of Strategic Industry Planning and Organizational Opportunities for Mexican Cantaloupe Producers}

\author{
J. Alberto García-Salazar ${ }^{1}$ \\ Economía Colegio de Postgraduados Km 36.5 Carr, México-Texcoco 56230 \\ Montecillo, Estado de México, México
}

\begin{abstract}
Rhonda K. Skaggs ${ }^{2,4}$ and Terry L. Crawford ${ }^{3}$
Department of Agricultural Economics and Agricultural Business, New Mexico State University, MSC 3169, Box 30003 88003, Las Cruces, NM 88003
\end{abstract}

Additional index words. Cucumis melo, profit, marketing order, strategy, storage, production planning, programming model

\begin{abstract}
Cantaloupe [Cucumis melo (L.)] producers in Mexico's Lagunera region harvest and sell their melons in the Mexican domestic market in June, July, and August. These producers and the larger Mexican cantaloupe industry have been economically battered in recent years by increasing competition in the global cantaloupe market, Salmonella contamination, low per-capita consumption relative to U.S. consumers, and historic supply gluts, which result in low prices and profits. A programming model of the region's cantaloupe industry was used to evaluate the impacts of strategic production planning, storage, or flow-to-market supply management. A $20 \%$ reduction in regional cantaloupe supply would increase growers' profits and release land for use in other cropping activities. Cantaloupe storage and strategic production planning would increase producers' profits but would require costly infrastructure investments. Organization of the regions' cantaloupe producers to achieve orderly and strategically planned production and marketing would not require costly infrastructure investments and would increase growers' profits. U.S. marketing orders for fruit, vegetable, and specialty crops are models under which Lagunera region cantaloupe industry planning and coordination could be effected. U.S. marketing orders have allowed producers to manage supply, promote their product to influence per-capita consumption, and deal with product quality and reliability threats.
\end{abstract}

The U.S. population has been exhorted by health experts for many years to consume more fresh fruits and vegetables, and they appear to have taken the advice to heart. Average percapita consumption of selected fresh fruits, vegetables, and melons in the United States was 193.5 pounds in 1976 and 281.8 pounds in 2008 (Lucier and Dettmann, 2008; Perez and Pollack, 2009).

U.S. consumers have developed a yearround appetite for fresh produce, much of which is imported from other countries. The import shares of fresh fruit and vegetable consumption in the United States were $30.7 \%$ and $9.3 \%$ in $1983-1985$, increasing to $44.4 \%$ and $16.3 \%$ in 2003-2005 (Huang and Huang, 2007). Although these products are sourced from all over the world, Mexico is a major player in the U.S. produce market, accounting for $59.8 \%$ of fresh vegetable and melon imports and $21.6 \%$ of fresh and frozen fruit imports (Lucier and Dettmann, 2008; Perez and Pollack, 2009).

Received for publication 15 July 2010. Accepted for publication 29 Nov. 2010

${ }^{1}$ Research Professor.

${ }^{2}$ Professor.

${ }^{3}$ Department Head.

${ }^{4}$ To whom reprint requests should be addressed; e-mail rskaggs@nmsu.edu.
Mexico's proximity to the U.S. market, its range of climate and growing conditions, and reduced trade barriers as a result of the North American Free Trade Agreement have led to Mexico's dominant position in the U.S. market for traditionally off-season produce. Mexican exporters of many fruit and vegetable products have benefited from their position in the U.S. market, although Mexican dominance is not without problems or threats. Other nations and regions are aggressively challenging Mexico's position in the U.S. market and U.S. phytosanitary restrictions have been and will continue to be a source of uncertainty for Mexican producers.

Although there is a high degree of complementarity between U.S. demand for and Mexican supplies of fresh fruits and vegetables, not all Mexican regions are export-oriented. Furthermore, domestic market producers and regions can be and have been very negatively impacted by events in U.S.-Mexico produce trade. The growing Mexican population, increasing incomes, and health concerns present domestic market opportunities for Mexican fruit and vegetable producers in non-export regions who strategically organize, produce, promote, and sell their products.

Cantaloupe melons [Cucumis melo (L.)] are produced in at least 13 different Mexican states, in every climatic zone, and by growers of all sizes for both the national and export markets. Seven percent of Mexican cantaloupe production was exported to the United States in 2007 with Mexico supplying only $2 \%$ of U.S. cantaloupe imports. Mexico previously accounted for $40 \%$ to $50 \%$ of U.S. cantaloupe imports; however, Mexico's share dropped sharply between 1999 and 2000 in the face of growing competition from Central American exporters benefiting from market access provisions of the U.S. Caribbean Basin Initiative (CBI) (Fig. 1). Mexico's share decline continued, and then in May 2002, contamination of Mexican cantaloupes by Salmonella Poona resulted in increased U.S. phytosanitary restrictions and further reductions in Mexican exports to the United States (HernándezMartínez et al., 2006). Total Mexican exports of cantaloupes were $136,637 \mathrm{t}$ in 1980 , increased to $275,915 \mathrm{t}$ in 1991 , and as a result of the events described, decreased to 136,513 t in 2007 (G. Lucier, Agricultural Economist, U.S. Dept. of Agr., Economic Res. Serv., personal communication, 2010).

Mexican cantaloupe production increased from $319,952 \mathrm{t}$ in 1980 to $543,336 \mathrm{t}$ in 2008 ; yields increased over the same period from $11.8 \mathrm{t} \cdot \mathrm{ha}^{-1}$ to $25.3 \mathrm{t} \cdot \mathrm{ha}^{-1}$ (SIAP-SAGARPA, 2009c). Per-capita cantaloupe consumption in Mexico was 6.0 pounds in 1980 and 8.6 pounds in 2007 , an increase of $44 \%$. In contrast, annual per-capita cantaloupe consumption in the United States increased almost $69 \%$ between 1980 and 2008 (from 5.7 pounds to 9.9 pounds) (Lucier and Dettmann, 2008)

Relative to other melon crops, cantaloupes face unique food safety challenges in both export and domestic markets. Cantaloupes are and will remain particularly vulnerable to potential bacterial contamination and phytosanitary restrictions or embargos. Rough webbing on the cantaloupe rind makes them more vulnerable to microbial contamination than other smooth-skinned melons (such as watermelons or honeydew melons) (Gereffi and Lee, 2009).

In response to the bacterial contamination problems described, the Mexican government developed mandatory guidelines dedicated to reducing food safety risks (Cervantes-Godoy et al., 2007). The industry is now segmented by export and domestic market quality standards. Mexican cantaloupe exporters' costs have risen as a result of the enhanced regulations, their competitiveness with CBI producers has been reduced, and relatively few firms now export (Aguilar-Huerta, 2009). Cantaloupe production previously exported is now sold domestically, increasing competition between, destabilizing the market, and lowering prices for all Mexican growers (SAGARPA, 2010).

The cantaloupe is the most important vegetable cultivated in northern Mexico's Lagunera region, where an average $119,000 \mathrm{t}$ of the crop are produced on an average 4,665 ha (SIAP-SAGARPA, 2009c). Lagunera region cantaloupe production occurs in the municipalities of Matamoros, San Pedro, Viesca, Tlahualilo, Mapimi, Gomez Palacio, and Lerdo and is the principle supplier of cantaloupes to the Mexican national market in the summer 


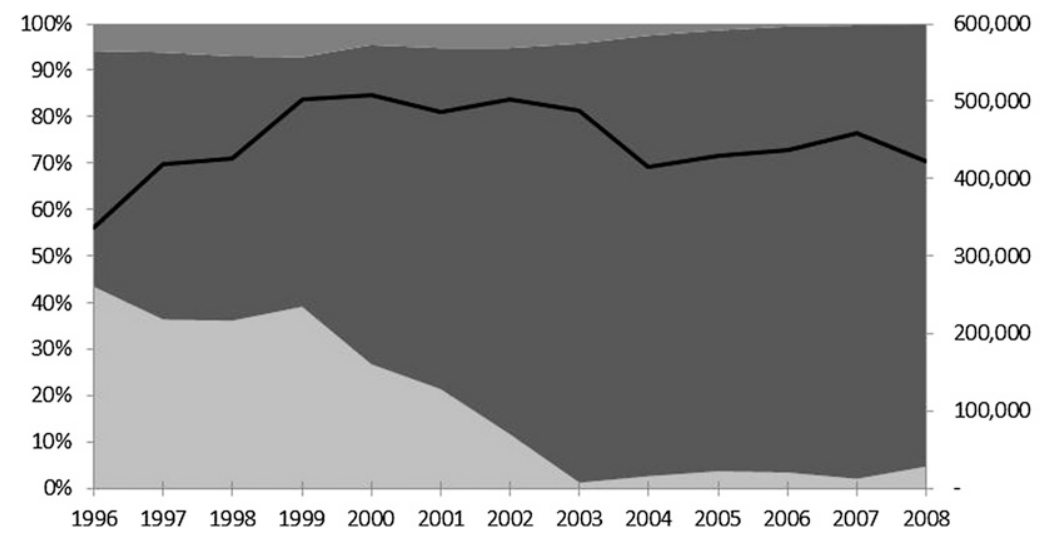

Rest of the World share

of US cantaloupe imports

Central American share

of US cantaloupe imports

Mexican share of US cantaloupe imports

- All US cantaloupe imports (Tons)

Fig. 1.

months. The majority of Lagunera cantaloupes are sold in the Mexico City, Puebla, and Guadalajara metropolitan areas (SAGARPARLCD, 2009).

Lagunera cantaloupe producers regularly experience low prices in the high production months of June, July, and August. For example, in 2006, 2007, and 2008, summer wholesale average prices for cantaloupes in Torreon were $47.9 \%, 39.7 \%$, and $22.3 \%$ lower than annual average prices, respectively. These low summer prices for cantaloupes are a function of seasonal excess supply with the inverse relationship between prices and production illustrated in Figure 1.

Simple regression analysis of regional average wholesale cantaloupe price as a function of Lagunera region cantaloupe production provides greater insight into the Mexican cantaloupe market. This equation was estimated using central moving averages of five monthly observations for both price and production for the period July 2005 to Feb. 2008. The regression analysis shows that if cantaloupe production in the Lagunera region increases by $1000 \mathrm{t}$, then the Torreon wholesale price decreases by 106 pesos/t; similarly, if cantaloupe production increases by $1000 \mathrm{t}$, wholesale prices in Mexico City, Monterrey, and Guadalajara decrease by 70,105 and 69 pesos/t, respectively (Table 1 ). The strong relationship between cantaloupe production and prices in the Lagunera region and the region's long-term dependence on the domestic market raise the question of whether supply or flow-to-market management would be able to increase and stabilize cantaloupe producers' prices and profits.

In past years, the now-defunct National Union of Horticultural Producers (UNPH) dealt with problems of excess supply and falling prices for exported horticultural products in Mexico. The UNPH attempted to regulate the timing of cantaloupe plantings and harvests to control quantities shipped to foreign markets. Using forecasts for each external market, UNPH delegates and cantaloupe producers determined the amount of land to be planted by state, thus avoiding episodes of excess supply and market saturation (Espinoza-Arellano, 2003). The UNPH functioned from the 1970 s until the early 1990s (Macías-Macías, 2000) and was officially renamed the National

Table 1. Regression results for relationship between cantaloupe production in the Lagunera region and wholesale prices in principal Mexican markets.

\begin{tabular}{lccccccc}
\hline & & & & Distrito & \multicolumn{2}{c}{ San Luis } \\
Indicator & Torreon & Monterrey & Guadalajara & Federal & Puebla & Toluca & Potosi \\
\hline Intercept & 5917 & 6161 & 6776 & 6763 & 6516 & 6789 & 5789 \\
$t_{\mathrm{c}}$ value & 72.63 & 61.66 & 49.80 & 40.30 & 46.72 & 37.03 & 51.83 \\
Coefficient & -0.106 & -0.105 & -0.069 & -0.070 & -0.071 & -0.052 & -0.074 \\
$t_{\mathrm{c}}$ value & -16.44 & -13.21 & -6.38 & -5.29 & -6.35 & -3.59 & -8.30 \\
$\mathrm{R}^{2}$ & 0.90 & 0.85 & 0.57 & 0.48 & 0.57 & 0.30 & 0.70 \\
Prob $>\mathrm{F}$ & 0.0001 & 0.0001 & 0.0001 & 0.0001 & 0.0001 & 0.0011 & 0.0001 \\
\hline
\end{tabular}

Confederation of Horticultural Producers in 1989. Since the UNPH was disbanded, fruit and vegetable producer organizations throughout Mexico have disappeared along with many of the flow-to-market management tools afforded by the UNPH.

Storage programs for vegetables have been implemented in several regions of the world, including in Colombia, for the purpose of managing excess potato supplies. However, experience in Latin America has shown that storage policies generally have not been successful in countries with limited capital resources. For example, high management costs were the primary cause of failed storage plans designed to stabilize potato production and prices in some regions of Colombia (Rodríguez-Borray, 2000).

In the past, Mexico's Lagunera region has attempted supply management through programmed planting of some crops. In the municipality of Tlahualilo, irrigation scheduling was used to stagger planting dates and was supported by rural development authorities [e.g., Centros de Apoyo al Desarrollo Rural (Espinoza-Arellano, 2003)].

In the United States, supply management for some fruit, vegetable, and specialty crops is done under the auspices of federal or state marketing orders and agreements. Currently, the U.S. Department of Agriculture reports federal marketing orders in effect for the following fruits, vegetables, and specialty crops: almonds, apricots, avocados, cherries, citrus, cranberries, dates, grapes, hazelnuts, kiwifruit, nectarines, olives, onions, peaches, pears, pistachios, plums/prunes, potatoes, spearmint oil, raisins, tomatoes, and walnuts (AMS-USDA, 2009). Numerous state-level marketing orders are also in effect. A full list of California marketing orders and marketing agreements can be found at http://www.cdfa.ca.gov/mkt/ mkt/ordslaws.html.

Marketing orders and agreements are authorized by the Agricultural Marketing Agreement Act of 1937 (as amended) and state-level enabling legislation and are legal instruments under which commodity producer groups can cartelize and work together to solve marketing problems. Federal and state marketing orders have been used in the United States to help growers in designated regions stabilize markets and increase growerlevel prices for several crops. Some marketing orders specify grade, size, quality, maturity, and container requirements; some regulate amounts that handlers may sell in specific markets through volume controls; and others authorize research and advertising activities. Marketing orders are binding on all crop handlers in the geographic area covered by an order, whereas marketing agreements are binding only on handlers who sign onto the agreement. Marketing orders were traditionally used by perishable crop producers to enhance revenues through the establishment of grower-level countervailing market power. Over time, many marketing orders have evolved into primarily promotional and information organizations. Currently, marketing order enabling legislation is being used by leafy green vegetable producers as a means to implement and enforce production and handling regulations in an industry that has been very negatively impacted by microbial contamination and loss of consumer confidence.

Both the national and regional cantaloupe industry governing plans noted that the Mexican cantaloupe market is subject to market saturation and would benefit from volume or flow-to-market controls. Volume controls 
enabled under U.S. marketing orders include shipping holidays, longer-term market shipments (e.g., prorates), market allocations, reserve pools, and marketing allotments. These grower-generated regulations can establish a ceiling on the maximum quantity of production that can enter certain markets during a season or a period within the season (Powers, 1990). Effective volume controls can raise producer returns by limiting supplies in markets or uses that are more inelastic while diverting supplies to markets or uses with higher elasticity of demand (Neff and Plato, 1995). Empirical findings suggest that volume controls can increase and stabilize farm-level prices (Carman and Pick, 1988; Kinney et al., 1987; Powers, 1990; Shepard, 1986; Thor and Jesse, 1981); thus, these mechanisms may have the potential to enhance Mexican cantaloupe producers' revenues and profits. Not using these tools results in a significant comparative disadvantage for the Mexican industry relative to U.S. fruit, vegetable, and specialty crop producers.

Cantaloupe melons are a case study in U.S.-Mexico market complementarity, market risks, and both disappearing and unexploited market opportunities. A case study of Mexican cantaloupes is presented here as an example of the information and data necessary for strategic industry efforts, which can improve Mexican growers' economic conditions.

This case study will be of interest to agribusinesses and agricultural sectors in Mexico and other countries that are attempting to stabilize agricultural subsectors, enhance growers' profits, and increase competitiveness. Recommendations for institutional and policy changes will be made here, drawing on examples from the United States.

Given the challenges facing Mexican cantaloupes, it is essential that Mexican producers strategically organize, plan, and position their industry. The need for strategic planning within the Mexican cantaloupe industry has been recognized at both the national and regional levels. This case study will illustrate opportunities for and potential outcomes of strategic industry efforts.

\section{Methodology}

An optimization model was used to examine opportunities for increased revenues and profits in the Mexican cantaloupe industry, specifically in the Lagunera region. The model incorporates the spatial and intertemporal dimensions of the region's cantaloupe market. Formulation of the model was based on microeconomic theory of the firm with the objective function of maximizing the total earnings of cantaloupe producers and cantaloupe industry middlemen. The results of this model illustrate strategic opportunities for cantaloupe producers in the Lagunera region and provide a template for planning and management for the larger Mexican cantaloupe industry.

Using the methods of Takayama and Judge (1971) and assuming $i(i=1,2 . I=7)$ Lagunera region municipalities where cantaloupes are produced, $j(j=1,2 . J=11)$ markets where the cantaloupes are sold, and $t(t=1,2 \cdot T=7)$ time periods, the model can be expressed as:

$$
\begin{aligned}
\operatorname{Max} G= & \sum_{t=1}^{T} \pi^{t-1} \sum_{i=1}^{I} \sum_{j=1}^{J} p c_{i j t} x_{i j t} \\
& -\sum_{t=1}^{T} \pi^{t-1} \sum_{i=1}^{I} c p_{i t} x_{i t} \\
& -\sum_{t=1}^{T} \pi^{t-1} \sum_{i=1}^{I} \sum_{j=1}^{J} c t_{i j t} x_{i j t} \\
& -\sum_{t=1}^{T} \pi^{t-1} \sum_{i=1}^{I} c a_{i t, t+1} x_{i t, t+1} \\
& -\sum_{t=1}^{T} \pi^{t-1} \sum_{i=1}^{I} \delta\left(p p_{i t} x_{i t, t+1}\right)
\end{aligned}
$$

Subject to:

$$
\begin{gathered}
\sum_{i=1}^{I} x_{i j t} \geq y_{j t} \\
\sum_{j=1}^{J} x_{i j t} \leq x_{i t}+x_{i t-1, t} \\
-\delta x_{i t-1, t}-x_{i t, t+1} \\
y_{j t}=\alpha_{j}\left[\sum_{i=1}^{I} \sum_{j=1}^{J} x_{i j t}\right] \\
y_{j t}, \quad x_{i j t}, x_{i t, t+1} \geq 0
\end{gathered}
$$

where for the month $t, \pi^{t-1}=\left(1 / 1+i_{t}\right)^{t-1}$ is the discount factor with $i_{t}$ equal to the inflation rate; $p c_{i j t}$ is the wholesale cantaloupe price in market $j$ coming from $i ; x_{i j t}$ is the quantity of cantaloupes shipped from municipality $i$ to market $j ; c p_{i t}$ is the cost of cantaloupe production in $i ; x_{i t}$ is the quantity of melon produced in $i ; c t_{i j t}$ is the cost of transportation from $i$ to $j ; c a_{i t, t+1}$ is the unit cost of storage in municipality $i$ from month $t$ to month $t+1 ; x_{i t, t+1}$ is the quantity of cantaloupes stored in $i$ from $t$ to $t+1 ; y_{j}$ is cantaloupe consumption in market $j ; \delta$ are percent shrinkages; $p p_{i t}$ is the producer price in $i$; and $\alpha_{j}$ is the share of market $j$ in total annual cantaloupe consumption.

The objective function [Eq. (1)] is subject to supply and demand restrictions. Eq. [2] indicates how market $j$ cantaloupe consumption is supplied; Eq. [3] defines how cantaloupe production in municipality $i$ is allocated; Eq. [4] states that cantaloupe consumption in market $j$ is equal to a percentage $\left(\alpha_{j}\right)$ of total consumption; and Eq. [5] establishes the model's non-negativity conditions.

The effect of Lagunera region cantaloupe production or availability on the wholesale price was specified as:

$$
\begin{aligned}
p c_{i j t}=\theta_{i j t} & +\eta_{i j t}\left[\sum_{i=1}^{I} x_{i t}+\sum_{i=1}^{I} \sum_{t=1}^{T} x_{i t-1, t}\right. \\
& \left.-\sum_{i=1}^{I} \sum_{t=1}^{T} x_{i t, t+1}\right]
\end{aligned}
$$

where $\theta_{i j t}$ and $\eta_{i j t}$ are the intercept and coefficient of a function measuring the relationship between the price in the market $j$ with the Lagunera region's total cantaloupe production in month $t$.

The cantaloupe producer price $\left(p p_{i j t}\right)$ was calculated by subtracting the marketing margin $\left(m_{i j t}\right)$ from the wholesale price:

$$
p p_{i j t}=p c_{i j t}-m_{i j t}
$$

Cantaloupe middlemen and producer profits are given by Eq. [8] and [9]:

$$
\begin{aligned}
G_{i n}= & \sum_{t=1}^{T} \pi^{t-1} \sum_{i=1}^{I} \sum_{j=1}^{J} p c_{i j t} x_{i j t} \\
& -\sum_{t=1}^{T} \pi^{t-1} \sum_{i=1}^{I} \sum_{j=1}^{J} p p_{i j t} x_{i j t} \\
& -\sum_{t=1}^{T} \pi^{t-1} \sum_{i=1}^{I} \sum_{j=1}^{J} c t_{i j t} x_{i j t} \\
G_{p r o}= & \sum_{t=1}^{T} \pi^{t-1} \sum_{i=1}^{I} \sum_{j=1}^{J} p p_{i j t} x_{i j t} \\
& -\sum_{t=1}^{T} \pi^{t-1} \sum_{i=1}^{I} c p_{i t} x_{i t} \\
& -\sum_{t=1}^{T} \pi^{t-1} \sum_{i=1}^{I} c a_{i t, t+1} x_{i t, t+1} \\
& -\sum_{t=1}^{T} \pi^{t-1} \sum_{i=1}^{I} \delta\left(p p_{i t} x_{i t, t+1}\right)
\end{aligned}
$$

Middlemen profits are equal to incomes derived from cantaloupe sales less the costs of buying the melons from growers and less transportation costs. Producer profits are equal to total revenues from sale of cantaloupes less production costs, storage costs, and shrinkage valued at producer prices.

The model was solved four times. The first solution was based on average annual actual Lagunera region cantaloupe market conditions for 2006, 2007, and 2008. The second solution included a $20 \%$ reduction in July and August cantaloupe production in the Lagunera region. A $20 \%$ reduction in production was chosen for the analysis because observed monthly production in July and August is often 20\% to $30 \%$ less than average monthly observed production in the period of analysis (2006-2008). This situation indicates that the $20 \%$ reduced production used in the model scenario is feasible. Although the federal government has no authority to force cantaloupe producers to reduce planted area or total output, it is conceivable that farm-level decisions to reduce area or production could be influenced by grower organizations, with support of the SAGARPA and state-level agencies, to avoid exceeding output thresholds that result in excess supply.

The third solution included a Lagunera region cantaloupe storage program and flowto-market controls. This scenario assumes that excess supply will be stored during some months rather than for the entire growing season. Producers in the municipalities of Tlahualilo and Mapimi recently implemented a storage program to stabilize prices; however, the current capacity of the storage 
warehouses is insufficient for significant supply management (CP-FONAES, 2002; GonzálezAlvarado, 2005). The fourth solution assumed that Lagunera region cantaloupe production was equal in every month during all production months. This assumption is reasonable because: 1) Lagunera region climatic conditions and soils are not an obstacle to this pattern of production; and 2) $100 \%$ of the region's cantaloupes are grown under irrigation. Programmed plantings would be necessary for this uniform output plan.

The first, second, and fourth solutions included the assumption that quantities of Lagunera region cantaloupes stored were zero in all months; the third solution's assumption was that the total quantities of cantaloupes marketed were 8,800 and 18,000 t in May and June, 23,200 t in July, August and September, and 10,000 $t$ in October and November.

The data used in the model came from several sources. Cantaloupe production data by municipality and month were obtained from the Sistema de Información Agropecuaria y Pesquera de la Secretaría de Agricultura, Ganadería, Desarrollo Rural, Pesca y Alimentación (SIAP-SAGARPA, 2009a, 2009c). Data for the distribution of Lagunera region cantaloupe in different markets were obtained from the Lagunera region SAGARPA delegation (SAGARPA-RLCD, 2009).

Monthly wholesale price data for cantaloupes in the relevant consumer markets are from the Sistema Nacional de Información e Integración de Mercados (SNIIM, 2009). Cantaloupe production costs were obtained from SIAP-SAGARPA (2009b); the producer-level price was derived from the wholesale price taking into account the marketing margin. Data used to obtain the producer-level price were from SIAP-SAGARPA (2009b) and SNIIM (2009).

Truck transportation costs include fees charged in 2009 and were obtained from individuals who move cantaloupe from the Lagunera region to Mexico City, Puebla, and Toluca. The average cost (pesos per $\mathrm{t} \cdot \mathrm{km}^{-1}$ ) was multiplied by the transportation distance matrix, which includes the destination cities of Monterrey, Mexico City, Guadalajara, Puebla, Toluca, Chihuahua, Aguascalientes, San Luis Potosi, Morelia, Leon, and Torreon; and the cantaloupe origin points of Matamoros, Viesca, and San Pedro in Coahuila and Tlahualilo, Ceballos, Gómez Palacio, and Lerdo in Durango. All monthly monetary values were deflated using the national consumer price index obtained from INEGI (2009).

All monthly data included in the model were 3-year averages; all averages from May to November were calculated using 2006, 2007 , and 2008 data. The model solution was obtained using the MINOS procedure written in GAMS (Brooke et al., 1998).

\section{Results and Discussion}

Lagunera region cantaloupe production and profits by month under different model scenarios are shown in Table 2 and Figure 2. During the period 2006-2008, cantaloupe production in the Lagunera region averaged
$116,329 \mathrm{t}$ per year with $75.1 \%$ of the supply generated in June, July, and August. Without storage, cantaloupe consumption was equal to production (Table 2), which was distributed among the seven municipalities as follows: $31.4 \%$ in Mapimí, 24.2\% in Matamoros, $16.6 \%$ in Viesca, $9.1 \%$ in Tlahualilo, $7.8 \%$ in San Pedro, $7.9 \%$ in Gomez Palacio, and $3.0 \%$ in Lerdo.

If all Lagunera region cantaloupe production had been sold at the actual prices in the average year, then producers' total incomes and profits would have risen to $218,590,000$ and 122,291,000 pesos, respectively. These amounts were calculated using monthly average wholesale prices; thus, producers who sold their cantaloupes for less than the average monthly price would have earned less.

Model results with the assumed $20 \%$ reduction in regional supply during the months of July and August are presented in Table 2. This change in supply volume is predicted to increase cantaloupe prices and improve producers' profits from 1051 to 1193 pesos/t. With the supply reduction, total profits from Lagunera region cantaloupe production would stay almost constant (e.g., 122,291,000 versus $122,622,000$ pesos), and growers would have the opportunity to use land released from cantaloupe production to grow other crops. The reduction in supply during the summer months could thus positively impact producer earnings.

Cantaloupe storage and flow-to-market controls are strategies that also show promise for increasing Lagunera region producers' revenues. These actions would consist of storing part of the region's cantaloupe production in the months of high supply to create a more uniform flow of the product into the market. Storage would occur during months of low prices with flow-to-market increasing during months when cantaloupes are relatively scarce and prices are higher. This volume management would help stabilize grower-level prices throughout the season by increasing prices during traditional low-price months and reducing prices received during months when cantaloupe prices are traditionally higher.

A large percentage of total production would have to be stored in June, July, August, September, and October to achieve the desired flow-to-market management of 23,169 $t$ during the months of July, August, and September; $10,000 \mathrm{t}$ in October; and 6,954 $\mathrm{t}$ in November. The level of necessary storage capacity would be $2,111,5,961,22,368,5,011$, and 2,612 $\mathrm{t}$ in June, July, August, September, and October, respectively. Because cantaloupes cannot be stored for more than $21 \mathrm{~d}$, monthly storage quantities would need to be less than monthly production in every month during which cantaloupes are harvested in the Lagunera region. With this storage and volume management plan, cantaloupe producer profits would be higher by $1,854,000$ pesos relative to the average baseline year.

Although storage and flow-to-market management can improve cantaloupe producers' economic conditions, this strategy has several limitations. First, extensive financial resources would be necessary to build, operate, and maintain the facilities used to store large volumes of cantaloupes during a few months of the year. This investment would be idle during most of the year because very little fall and winter vegetable production occurs in the Lagunera region; underuse of warehouses and a low rate of return on the facilities investment would be realized. Another problem for the industry would be increased shrinkage and product deterioration during the storage process, resulting in reduced producer revenues and profits.

The fourth scenario explored in the model involves strategic production planning over time. If cantaloupe availability by municipality were equal in every month during which cantaloupe production in the Lagunera region is possible, then temporary excess supplies would disappear. This strategic effort would require staggered, uniform production over time. For example, if cantaloupe production in a particular municipality enters the market over a 2- (or 4-) month period, then no more than $50 \%$ (or $25 \%$ ) could be marketed every month. Planned production and uniform flowto-market in the Lagunera region would increase producers' profits by $23,616,000$ pesos relative to the baseline scenario. This positive impact leads to the conclusion that, of the three scenarios presented, planned production is the best strategy for cantaloupe producers in the Lagunera region (Fig. 2). The planned production strategy would not require costly infrastructure investments and would improve growers' economic conditions; however, the strategy would require a high degree of industry coordination and cooperation.

Espinoza-Arellano et al. (2005) report that Lagunera region cantaloupe producers are poorly organized and act as individual agents in ways that reduce their negotiation power with industry middlemen. Therefore, in the absence of improved producer-level organization and planning, top-down manipulation of water availability could help achieve improved economic conditions for cantaloupe growers. With $100 \%$ of cantaloupe production in the Lagunera region occurring under irrigation (both gravity-fed and pumped water), implementation of a regional irrigation schedule could be used to influence production planning and uniform flow-to-market.

Regardless of the type of strategic production planning, storage, or flow-to-market management, any of these interventions will have only moderate effects on producer profits. This is because of the large marketing margin (up to $60 \%$ of the wholesale price) that exists between cantaloupe growers and cantaloupe traders (e.g., middlemen). However, any form of strategic production planning, storage, or flow-to-market management would also be expected to aid in improving growers' market position and create conditions for their increased negotiating power.

\section{Conclusions and Recommendations}

Mexico's reorientation of agricultural policy since the late 1980 s has led to reduced 
Table 2. Lagunera region cantaloupe production, storage, and profits by month under different scenarios or strategies.

\begin{tabular}{|c|c|c|c|c|c|c|c|c|}
\hline Month & Production & Storage & Availability $^{z}$ & $\begin{array}{l}\text { Producer } \\
\text { income }\end{array}$ & $\begin{array}{l}\text { Production } \\
\text { cost }\end{array}$ & $\begin{array}{c}\text { Storage } \\
\text { cost }^{\mathrm{y}}\end{array}$ & $\begin{array}{l}\text { Producer } \\
\text { profits }^{\mathrm{x}}\end{array}$ & $\begin{array}{l}\text { Middlemen } \\
\text { profits }^{\mathrm{w}}\end{array}$ \\
\hline \multicolumn{9}{|c|}{ Actual (baseline) Lagunera region cantaloupe situation, annual average, 2006-2008 } \\
\hline July & 27,188 & 0 & 27,188 & 46,884 & 22,782 & 0 & 24,101 & 65,865 \\
\hline Aug. & 40,053 & 0 & 40,053 & 61,557 & 33,879 & 0 & 27,678 & 66,509 \\
\hline Sept. & 7,601 & 0 & 7,601 & 18,772 & 6,454 & 0 & 12,318 & 23,341 \\
\hline Total & 116,329 & 0 & 116,329 & 218,590 & 96,297 & 0 & 122,291 & 277,126 \\
\hline \multicolumn{9}{|c|}{$20 \%$ decrease in July and August Lagunera region cantaloupe production } \\
\hline May & 8,823 & 0 & 8,823 & 20,468 & 7,027 & 0 & 13,441 & 27,927 \\
\hline June & 20,111 & 0 & 20,111 & 40,159 & 15,846 & 0 & 24,313 & 53,709 \\
\hline July & 21,751 & 0 & 21,751 & 40,687 & 18,226 & 0 & 22,461 & 58,056 \\
\hline Aug. & 32,041 & 0 & 32,041 & 56,804 & 27,102 & 0 & 29,702 & 64,186 \\
\hline \multicolumn{9}{|c|}{ Storage and Lagunera region cantaloupe flow-to-market controls implemented } \\
\hline May & 8,823 & 0 & 8,823 & 20,469 & 7,027 & 0 & 13,442 & 27,926 \\
\hline June & 20,111 & 2,111 & 18,000 & 37,204 & 15,846 & 695 & 20,663 & 46,842 \\
\hline July & 27,188 & 5,961 & 23,169 & 44,174 & 22,782 & 1,745 & 19,646 & 51,867 \\
\hline Aug. & 40,053 & 22,368 & 23,169 & 47,336 & 33,879 & 7,162 & 6,295 & 26,760 \\
\hline Sept. & 7,601 & 5,011 & 23,169 & 45,323 & 6,454 & 1,452 & 37,417 & 83,048 \\
\hline Oct. & 8,002 & 2,612 & 10,000 & 22,117 & 6,286 & 829 & 15,002 & 33,272 \\
\hline Nov. & 4,551 & 0 & 6,954 & 15,703 & 4,023 & 0 & 11,680 & 24,397 \\
\hline Total & 116,329 & 38,063 & 113,284 & 232,326 & 96,297 & 11,883 & 124,145 & 294,112 \\
\hline \multicolumn{9}{|c|}{ Lagunera region cantaloupe production planning over time implemented } \\
\hline May & 6,771 & 0 & 6,771 & 16,006 & 5,538 & 0 & 10,468 & 22,094 \\
\hline June & 23,019 & 0 & 23,019 & 44,222 & 18,869 & 0 & 25,353 & 58,083 \\
\hline
\end{tabular}

${ }^{2}$ Cantaloupe availability (consumption) in the month $t$ is equal to production in the month $t$, plus inventories from month $t-1$ to month $t$, less shrinkages in the product stored from month $t-1$ to month $t$, less inventories from month $t$ to month $t+1$.

${ }^{\mathrm{y}}$ Includes shrinkages.

${ }^{x}$ Producer profits are equal to producer income less production cost and storage costs.

wMiddlemen profits are equal to incomes derived from cantaloupe sales less the costs of buying melons from growers less transportation costs.

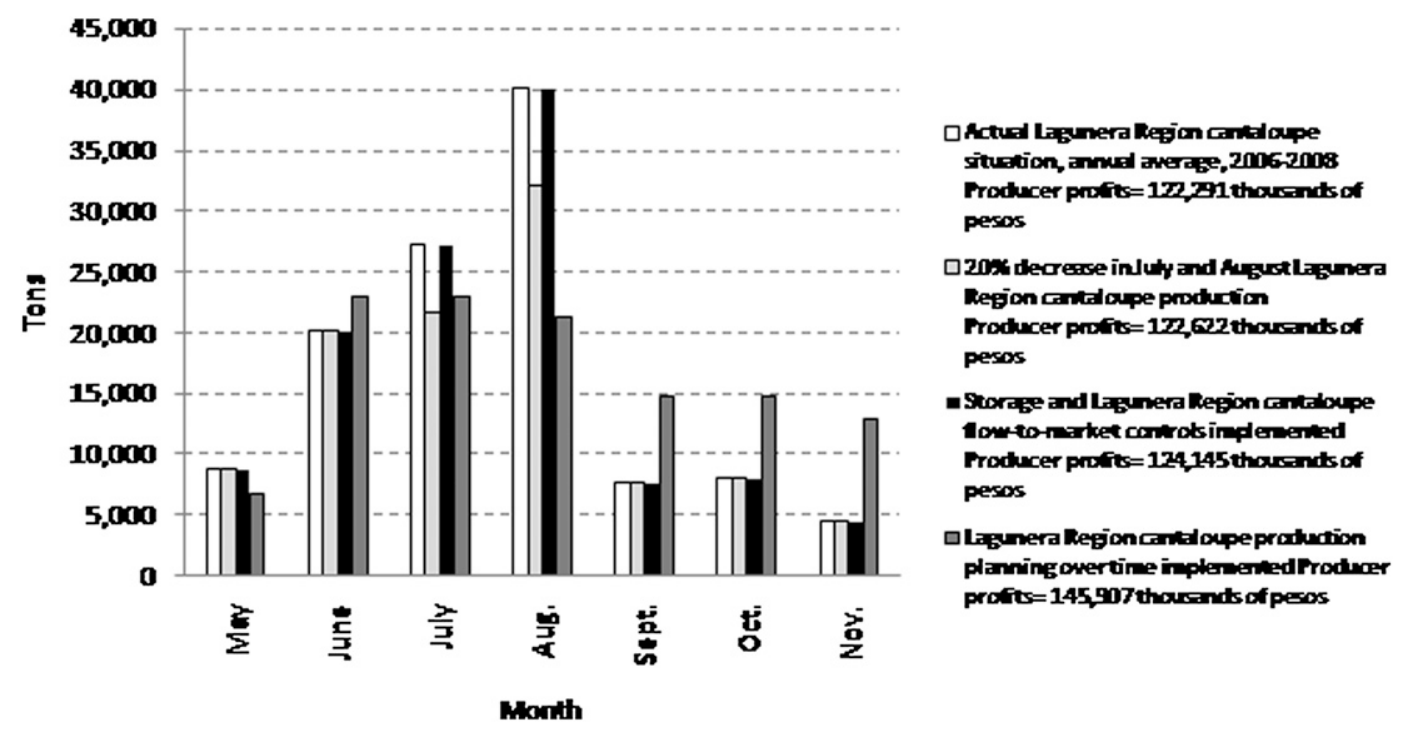

Fig. 2. Lagunera region cantaloupe production and profits by month under different scenarios and strategies, 2006-2008. 
producer-level horticultural industry planning and coordination of growing and marketing activities, especially relative to their counterparts in the United States. U.S. fruit, vegetable, and specialty crop producers actively take advantage of legislation, which permits them to organize in the interest of orderly marketing (although the exact definition of "orderly" is not well defined) (Helmberger, 1991). Price discrimination achieved through supply management allows producers to stabilize their markets and enhance their revenues. Current U.S. marketing order policies authorize grower groups to assess themselves and use the funds generated to support group activities, including advertising and promotion of their product. Some industry funds also are used to support research activities of benefit to the industry, including extensive economic analysis of the characteristics of product demand, specifically price elasticities. Knowledge of elasticities permits optimum price discrimination, crop allocation among alternative outlets, and revenue enhancement. Most recently, marketing order enabling legislation has been used to create a framework for protecting producers from foodborne illness catastrophes, similar to that which destroyed the U.S. market for Mexican cantaloupes.

U.S. marketing orders are designed to reduce competition and operate as governmentenforced cartels (Filson et al., 2001). They are used by agricultural producers to improve their industry's market position by facilitating collective action. The supply control provisions of U.S. agricultural marketing orders were criticized heavily in the 1980s, and some orders have been vacated for a variety of reasons (including disagreements over quality standards and producer demands for freedom to make their own production and marketing decisions). However, many continue and new orders or agreements will likely be developed in the future by industries seeking to organize for the purpose of improving product quality and reliability.

Results of scenario analysis using a regional cantaloupe industry model indicate that Mexican producers of this commodity in the Lagunera region could improve their economic condition with strategic planning and organization. Strategic production, storage, and flow-to-market management; advertising and promotion designed to increase domestic cantaloupe consumption; and industry-mandated good practices designed to reduce microbial contamination of cantaloupes would benefit Mexico's domestic market and export-oriented cantaloupe producers. As noted, Mexican fruit and vegetable producers have a large, and very vulnerable, role in the U.S. fresh produce market. Both domestic and export market producers are impacted by shocks to and trends in U.S.-Mexico trade.

In summary, since the 1930s, marketing orders and marketing agreements have facilitated U.S. producers' strategic industry efforts. Similar strategic planning and organization by Mexican producers would enhance their competitive positions both domestically and abroad. This analysis indicates that Mexican cantaloupe producers would benefit from the types of coordinated activities that currently benefit many U.S. fresh fruit, vegetable, and specialty crop producers.

\section{Literature Cited}

Aguilar-Huerta, A. 2009. A punto de desaparecer el cultivo de melón. Ecos de la Costa, Manzanillo, Colima, 20 Oct. 2009. 15 Apr. 2010. <http:// www.campomexicano.gob.mx/portal_sispro/ noticias.php?id_noticia $=2995>$.

AMS-USDA (Agricultural Marketing ServiceUnited States Department of Agriculture). 2009. Marketing order commodity index, industrial marketing and promotion. 17 May 2009. <http://www.ams.usda.gov>

Brooke, A., D. Kendrick, A. Meeraus, and R. Raman. 1998. GAMS a user's guide. GAMS Dev. Corporation, Washington, DC.

Carman, H.F. and D.H. Pick. 1988. Marketing California-Arizona lemons without marketing order shipments controls. Agribusiness Intl. J. 4:245-259.

Cervantes-Godoy, D., D. Sparling, B. Avedaño, and L. Calvin. 2007. North American retailers and their impact on food chains. North American Agrifood Market Integration Consortium Workshop IV: Contemporary Drivers of Integration, 8 Jan. 2010. <http://naamic.tamu.edu/cancun2/ sparling.pdf $>$.

CP-FONAES (Colegio de Postgraduados-Fondo Nacional de Apoyos para Empresas en Solidaridad). 2002. Estudio de pre-inversión, melón, Durango. Colegio de Postgraduados. Montecillo, Estado de México, México.

Espinoza-Arellano, J.J. 2003. Programación de siembras de melón en la Comarca Lagunera. El Siglo de Torreón, Torreón, Coahuila, 17 Aug. 2003. 15 May 2009. <http://www.elsiglodetorreon. com.mx/noticia/45056.siglo>.

Espinoza-Arellano, J.J., I. Orona-Castillo, and P. Cano-Ríos. 2005. Situación y tendencias en las actividades de producción y comercialización de melón (Cucumis melo L.) en la Comarca Lagunera, Mexico. Agrofaz. Publicación Semestral de Investigación Científica 5:801-811.

Filson, D., E. Keen, E. Fruits, and T. Borcherding. 2001. Market power and cartel formation: Theory and an empirical test. J. Law Econ. 44:465-480.

Gereffi, G. and J. Lee. 2009. A global value chain approach to food safety and quality standards. Global Health Diplomacy for Chronic Disease Prevention Working Paper Series. 26 Jan. 2010. $<$ http://www.cggc.duke.edu/pdfs/GlobalHealth/ Gereffi_Lee_GVCFoodSafetyl_4Feb2009.pdf>.

González-Alvarado, H. 2005. Meloneros requieren de la infraestructura. El Siglo de Torreón, Torreón, Coahuila, 16 Dec. 2005. 28 Sept. 2010. $<$ http://www.elsiglodetorreon.com.mx/noticia/ 186813.html>.

Helmberger, P.G. 1991. Economic analysis of farm programs. McGraw-Hill, New York, NY.

Hernández-Martínez, J., J.A. García-Salazar, J.S Mora-Flores, R. García-Mata, R. ValdiviaAlcalá, and M. Portillo-Vazquez. 2006. Efectos de la eliminación de aranceles sobre las exportaciones de melón (Cucumis melo L.) de México a los Estados Unidos. Agrociencia 40:395-407.

Huang, S. and K. Huang. 2007. Increased U.S. imports of fresh fruit and vegetables. U.S. Dept. of Agr., Economic Res. Serv., FTS-328-01. 26 Jan. 2010. $<\mathrm{http}$ //www.ers.usda.gov/Publications/fts/2007/ 08Aug/fts32801/fts32801.pdf>.

INEGI (Instituto Nacional de Estadística Geografía e Informática). 2009. Precios e Inflación. 18 May 2009. <http://www.inegi.gob.mx>.
Kinney, W., H. Carman, R. Green, and J. O'Connell. 1987. An analysis of economic adjustment in the California-Arizona lemon industry. Giannini Foundation Res. Rpt. No. 337. California Agricultural Expt. Sta., Berkeley, CA.

Lucier, G. and R.L. Dettmann. 2008. Vegetables and melons situation and outlook yearbook. U.S. Dept. of Agr., Economic Res. Serv., VGS2008. 19 Jan. 2010. <http://www.ers.usda.gov/ publications/VGS/2008/05May/VGS2008.pdfs.

Macías-Macías, A. 2000. La importancia de las organizaciones de productores en la hortofruticultura de Mexico. El caso de la sandia en la costa de Jalisco. Carta Econ. Reg. 73:3-14.

Neff, S.A. and G.E. Plato. 1995. Federal marketing orders and federal research and promotion programs: Background for 1995 farm legislation. U.S. Dept. of Agr., Economic Res. Serv., Agricultural Economic Rpt. 707. Washington, DC.

Perez, A. and S. Pollack. 2009. Fruit and tree nuts situation and outlook yearbook 2009. U.S. Dept. of Agr., Economic Res. Serv., FTS2009. 19 Jan. 2010. <http://www.ers.usda.gov/ publications/FTS/Yearbook09/FTS2009.pdf $>$.

Powers, N.J. 1990. Federal marketing orders for fruits, vegetables, nuts, and specialty crops. U.S. Dept. of Agr., Economic Res. Serv., Agricultural Economic Rpt. 629. Washington, DC.

Rodríguez-Borray, G.A. 2000. Almacenamiento de papa para consumo directo e industrial, $\mathrm{p}$. 170-179. In: Herrera, C.A., L.H. Fierro, and J.D. Moreno (eds.). Manejo Integrado del Cultivo de la Papa. Corporación Colombiana de Investigación Agropecuaria (CORPOICA), Bogotá, Colombia.

SAGARPA (Secretaría de Agricultura, Ganadería, Desarrollo Rural, Pesca y Alimentación). 2010. Plan Rector Sistema Producto Nacional Melón. 18 Feb. 2010. <http://www.sagarpa.gob.mx/v1/ subagri/info/sp/melon/prn_melon.pdf $>$.

SAGARPA-RLCD (Secretaría de Agricultura, Ganadería, Desarrollo Rural, Pesca y Alimentación-Región Lagunera Coahuila-Durango). 2009. Plan Rector del Sistema-Producto Melón, Comarca Lagunera. 21 May 2009. <http://www. melon.gob.mx>.

Shepard, L. 1986. Cartelization of the CaliforniaArizona orange industry, 1934-1981. J. Law Econ. 29:83-123.

SIAP-SAGARPA (Servicio de Información Agroalimentaria y Pesquera-Secretaría de Agricultura, Ganadería, Desarrollo Rural, Pesca y Alimentación). 2009a. Avance de Siembras y Cosechas. 21 May 2010. <http://www.siap.sagarpa.gob.mx>.

SIAP-SAGARPA (Servicio de Información Agroalimentaria y Pesquera-Secretaría de Agricultura, Ganadería, Desarrollo Rural, Pesca y Alimentación). 2009b. Sistema Producto, Melón, Producción, Costos. 20 May 2009. <http://www.melon. gob.mx>.

SIAP-SAGARPA (Servicio de Información Agroalimentaria y Pesquera-Secretaría de Agricultura, Ganadería, Desarrollo Rural, Pesca y Alimentación). 2009c. Producción Anual. 20 May 2009. <http:// www.siap.sagarpa.gob.mx>.

SNIIM (Sistema Nacional de Información e Integración de Mercados). 2009. Mercados Nacionales, Precios de Mercado, Mercados Agrícolas, Frutas y Hortalizas. 21 May 2009. <http://www. secofi-sniim.gob.mx/nuevo>.

Takayama, T. and G.G. Judge. 1971. Spatial and temporal price and allocation models. NorthHolland Publishing Co. Amsterdam, Holland.

Thor, P.K. and E.V. Jesse. 1981. Economic effects of terminating federal marketing orders for California-Arizona oranges. U.S. Dept. of Agr., Economic Res. Serv., TB-1664, Washington, DC. 